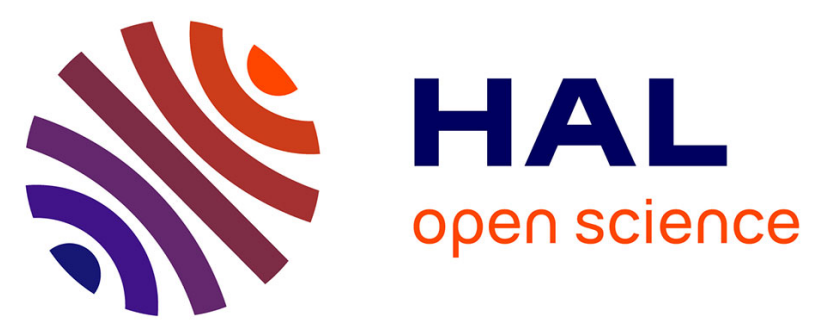

\title{
Serum-free SFM corneal organ culture medium but not conventional MEM organ culture medium protects human corneal endothelial cells from apoptotic and necrotic cell death
}

\author{
Thekla Jaeckel, Lilla Knels, Monika Valtink, Richard Hw Funk, Katrin
}

Engelmann

\section{To cite this version:}

Thekla Jaeckel, Lilla Knels, Monika Valtink, Richard Hw Funk, Katrin Engelmann. Serum-free SFM corneal organ culture medium but not conventional MEM organ culture medium protects human corneal endothelial cells from apoptotic and necrotic cell death. British Journal of Ophthalmology, 2010, 95 (1), pp.123. 10.1136/bjo.2010.183418 . hal-00588493

\section{HAL Id: hal-00588493 https://hal.science/hal-00588493}

Submitted on 24 Apr 2011

HAL is a multi-disciplinary open access archive for the deposit and dissemination of scientific research documents, whether they are published or not. The documents may come from teaching and research institutions in France or abroad, or from public or private research centers.
L'archive ouverte pluridisciplinaire HAL, est destinée au dépôt et à la diffusion de documents scientifiques de niveau recherche, publiés ou non, émanant des établissements d'enseignement et de recherche français ou étrangers, des laboratoires publics ou privés. 


\section{Serum-free SFM corneal organ culture medium but not conventional MEM organ}

culture medium protects human corneal endothelial cells from apoptotic and necrotic cell death

Thekla Jäckel ${ }^{1}$, Lilla Knels ${ }^{1}$, Monika Valtink ${ }^{1}$, Richard H.W. Funk ${ }^{1,2}$, Katrin Engelmann ${ }^{2,3}$

${ }^{1}$ Institute of Anatomy, Medical Faculty, TU Dresden, Germany

${ }^{2}$ CRTD / DFG-Center for Regenerative Therapies Dresden - Cluster of Excellence, TU Dresden, Dresden, Germany

${ }^{3}$ Dept. of Ophthalmology, Klinikum Chemnitz gGmbH, Chemnitz, Germany

\section{Corresponding author:}

Monika Valtink

Institute of Anatomy

Medical Faculty Carl Gustav Carus, TU Dresden

Fetscherstr. 74

01307 Dresden

Germany

phone: +49-351-458-6124 fax: $+49-351-458-6303$

e-mail: monika.valtink@tu-dresden.de

key words: human corneal endothelium, serum-free medium, protection, apoptosis, corneal organ cultivation medium

word count: 3096 


\section{ABSTRACT}

Aim: To evaluate the influence of organ culture media on corneal endothelial cell survival.

Methods: The human corneal endothelial cell line HCEC-12 was cultured in five different media: HCEC growth medium F99 $9_{\text {HCEC }}$, standard corneal organ culture medium MEM+2\% FCS, MEM+5\% FCS, and humanised, serum-free medium Endothelial-SFM (with and without antibiotics). Part of the cells were treated with $0.5 \mu \mathrm{mol} / \mathrm{l}$ staurosporine and examined for signs of apoptosis by assessing mitochondrial membrane polarisation state (intravital JC1 staining), YO-PRO-1 and propidium iodide staining, determining fragmentation of nuclei by sub-G1 DNA content, immunocytochemistry for cleaved caspase-3, cleaved caspase-8, Bax, Bcl-2, and western blotting for cleaved caspase-3 and cleaved PARP.

Results: The number of apoptotic cells in untreated control cultures was significantly higher in MEM compared to $\mathrm{F} 99_{\mathrm{HCEC}}$ and SFM. Staurosporine treatment induced apoptosis in all tested cultures to varying degrees. Cells cultured in MEM showed stronger staining for cleaved caspase-3, cleaved caspase-8, Bax, Bcl-2, and cleaved PARP, increased sub-G1 DNA content, more propidium iodide and YO-PRO-1 positive cells, and more mitochondria with depolarised membranes. All parameters were significantly higher in MEM compared to F99 $9_{\text {HCEC }}$ and SFM. SFM cultures were significantly less susceptible to cell stress.

Conclusion: SFM is superior to MEM in promoting HCEC survival. 


\section{INTRODUCTION}

Corneal grafts can easily be preserved in organ culture, but corneal endothelial cell count declines notably about $20-30 \%$ during cultivation.[1] This decline continues post-surgically depending upon pre- and post-surgical risk factors.[2-5] Consequently, maintenance of graft function depends on a relatively low number of viable endothelial cells compared to healthy corneas of the same age. Hence reducing endothelial cell loss during in vitro cultivation, e.g. by ameliorating cultivation conditions, seems crucial. Most european eye banks use MEM (Minimal Essential Medium) supplemented with $2-8 \%$ fetal calf serum (FCS) as culture medium. Optimising corneal organ cultivation conditions does also include elimination of serum supplementation, because serum is a complex and varying mixture of different substances, some of them not yet determined, and underlies batch-dependent quality differences.[6,7]

Physical contact between the corneal graft and undefined, possibly pathogenic serum constituents is posing a risk to the graft recipient. Cultivation of corneal grafts in a defined serum-free medium can help avoid this risk and meets European laws and standards for handling tissue transplants.[8,9]

In previous studies we investigated the effects of nine different culture media on human corneal endothelial cell (HCEC) morphology and metabolism in HCEC cultures and whole corneas. We observed that the low nutritive content of MEM is inadequate to sustain sufficient corneal endothelial metabolic activity. We could further demonstrate that corneal grafts cultured in Human Endothelial-SFM (serum-free medium, hereafter abbreviated SFM), a humanised and fully defined culture medium, showed lowest endothelial cell loss, highest RNA synthesis rate, lowest keratan sulphate leakage, highest utilisation of glucose and lactate production.[10-13] Additional experiments demonstrated that even after prolonged organ cultivation of up to 9 weeks serum-free SFM markedly supported endothelial cell 
survival and morphology, as well as keratocyte viability.[12,13] Therefore we considered Human Endothelial-SFM superior to other conventional culture media, which needed serum supplementation. Here, we compared the effects of organ culture medium on HCEC survival and protection of apoptosis and necrosis at a subcellular level.

\section{MATERIALS AND METHODS}

\section{Cell culture and test media}

The immortalized HCEC population HCEC-12, which was established by Bednarz et al. [14] and further characterized by Valtink et al. [15], was routinely grown in F99 ${ }_{\text {HCEC }}$ (Ham's F12/Medium 199 [Biochrom AG, Berlin, Germany], 5\% FCS [Invitrogen, Karlsruhe, Germany], 20 $\mathrm{g} / \mathrm{ml}$ ascorbic acid [Sigma-Aldrich, Munich, Germany], $10 \mathrm{ng} / \mathrm{ml}$ human

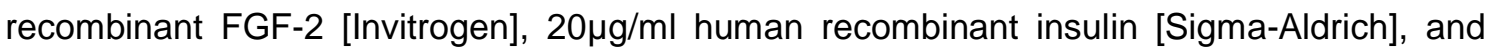
antibiotics [2.5 $\mathrm{g} / \mathrm{ml}$ amphotericin B and $50 \mu \mathrm{g} / \mathrm{ml}$ gentamycin, Biochrom]). For subcultivation, cells were detached with trypsin/EDTA $(0.05 \% / 0.02 \%$, Biochrom $)$, collected in growth medium, centrifuged at $100 \mathrm{xg}$ for $5 \mathrm{~min}$ and plated at a density of $2000 \mathrm{cells} / \mathrm{cm}^{2}$. Cultures were grown in T75 tissue culture flasks coated with $10 \mu \mathrm{g} / \mathrm{ml}$ laminin (Invitrogen) and $10 \mathrm{mg} / \mathrm{ml}$ chondroitin sulphate (Sigma) solubilised in phosphate-buffered saline (PBS) for $1 \mathrm{~h}$ at RT. Cells were maintained at $37^{\circ} \mathrm{C}$ in a humidified atmosphere containing $5 \% \mathrm{CO}_{2}$. Growth medium was changed $3 x$ per week. For experiments, medium was changed to test media $24 \mathrm{~h}$ after plating and cells were cultured for 5days (flow cytometry) or until confluence (immunocytochemistry). Test media were MEM (Biochrom) supplemented with $2 \mathrm{mM}$ Lglutamine (Biochrom), antibiotics and either $2 \%$ FCS or $5 \%$ FCS, and serum-free Human Endothelial-SFM (Invitrogen) supplemented with 10ng/ml FGF-2 and either with or without 
antibiotics. Medium SFM was used with and without antibiotics, because we observed a higher sensitivity of HCEC towards antibiotics in serum-free culture in preliminary experiments. HCEC cultured in growth medium F99 ${ }_{\text {HCEC }}$ served as controls.

\section{Induction of apoptosis and ROS production}

Apoptosis via the mitochondrial pathway (intrinsic) was induced by incubating the cells with $0.5 \mu \mathrm{mol} / / \mathrm{l}$ staurosporine for $4 \mathrm{~h}$ at $37^{\circ} \mathrm{C}$. It was shown that staurosporine induces caspasedependent apoptosis in HCEC and that markers of apoptosis such as cleaved caspase- 3 and cleaved PARP are observable within less than $4 \mathrm{~h}$ after induction.[16,17] A concentration of $0.5 \mu \mathrm{mol} / /$ sufficiently induces apoptosis in the majority of susceptible cells. Generation of ROS was induced by incubating the cells with $200 \mu \mathrm{mol} / / \mathrm{H}_{2} \mathrm{O}_{2}$ for $2.5 \mathrm{~h}$ at $37^{\circ} \mathrm{C}$. Cells were photodocumented using differential interference contrast (DIC) under an IX81 fluorescence microscope (Olympus Biosystems, Hamburg, Germany) equipped with an OBS CCD FV2T camera (Olympus) driven by cell^R software (Olympus).

\section{Flow cytometry}

Flow cytometric analyses were performed using a FACS-Calibur (Becton Dickinson GmbH, Heidelberg, Germany). 10,000 cells were recorded for each analysis and calculations were performed with BD CellQuest ${ }^{\mathrm{TM}}$ software. For detection of apoptotic cells (subG1-DNA content), cells were trypsinised, pelleted at $195 \mathrm{xg}$ for $6 \mathrm{~min}$, and fixed in cold $70 \%$ ethanol for 5 min on ice. $50 \mu$ l of PBS containing $1 \mu$ l propidium iodide solution $\left(1 \mathrm{mg} / \mathrm{ml} \mathrm{PI}\right.$ in $\mathrm{H}_{2} \mathrm{O}$; SigmaAldrich) and $1 \mu \mathrm{l}$ RNase (>7 U/ $\mu$ l, Carl Roth $\mathrm{GmbH}$, Karlsruhe, Germany) were added, followed by incubation for $30 \mathrm{~min}$ at RT in the dark. Apoptotic cells were identified by a subdiploid DNA peak (fragmented chromatin) using a $585 \pm 21 \mathrm{~nm}$ filter (red fluorescence). Apoptotic cells were further identified by labelling chromatin after nuclear membrane destabilisation with YO-PRO-1. Cells were collected as above, resuspended in 50 $\mu$ PBS with 
1\% horse serum (Sigma-Aldrich) containing $1 \mu \mathrm{l}$ YO-PRO-1 (100 $\mu \mathrm{mol} / \mathrm{I}$ in DMSO, Invitrogen) and $1 \mu \mathrm{l} \mathrm{PI}$ solution, and incubated for $25 \mathrm{~min}$ at $\mathrm{RT}$ in the dark. Cells were analysed using a $530 \pm 15 \mathrm{~nm}$ filter for YO-PRO-1 (green fluorescence) and a $585 \pm 21 \mathrm{~nm}$ filter for PI. The percentages of necrotic (PI high positive) and apoptotic (PI low positive, YO-PRO-1 positive) cells were calculated. Formation of intracellular reactive oxygen species (ROS) was measured using $\mathrm{CM}-\mathrm{H}_{2}$ DCFDA (Invitrogen), a cell-permeant indicator which becomes fluorescent in the presence of ROS. Cells were collected as above, resuspended in $50 \mu \mathrm{CM}$ $\mathrm{H}_{2}$ DCFDA $\left(10 \mu \mathrm{mol} / / \mathrm{l}\right.$ in PBS) and incubated at $37^{\circ} \mathrm{C}$ for $30 \mathrm{~min}$ in the dark. Fluorescence was recorded using a $530 \pm 15 \mathrm{~nm}$ filter. All assays were performed at least six times, values are given as mean $\pm S D$. Statistical analysis was performed by non-parametric Mann-Whitney-Utest using SPSS (Chicago, USA) between different media (untreated cells) and between treated and untreated pairs for each medium. Alpha error adjustment by Mann-Whitney-Utest was performed with respect to the necessity of alpha error adjustment in multiple testing and with a total alpha error of $5 \%(0.05)$ for a total of 15 p-values ( 5 comparisons of pairs treated/untreated in the same medium and 10 comparisons of untreated cells in all five media among each other, resulting in 15 p-values). An adjusted p-value $<0.05 / 15(0.0033)$ was accepted as significant.

\section{Intravital microscopy and immunocytochemistry}

Cells were seeded into 8-chamber slides (Labtek coverglass system, Nalge Nunc International, New York, USA) and grown to confluence. Intravital staining was performed with JC-1 $\left(20 \mu \mathrm{g} / \mathrm{ml}\right.$ medium; Invitrogen) at $37^{\circ} \mathrm{C}$ for $20-30 \mathrm{~min}$. JC-1 is a cationic dye that selectively accumulates within the mitochondrial matrix. JC-1 forms red fluorescent $\mathrm{J}$ aggregates (emission $590 \mathrm{~nm}$ ) in the presence of a highly negative transmembrane potential, but exists as green monomers (emission $530 \mathrm{~nm}$ ) under depolarised conditions. The red phase of JC-1 (J-aggregate) was recorded using an excitation wavelength of $535 \mathrm{~nm}$ and an 
emission filter of $610 / 75 \mathrm{~nm}$. The green phase (monomer) was recorded using an excitation wavelength of $485 \mathrm{~nm}$ and an emission filter of $540 / 50 \mathrm{~nm}$.

Immunocytochemical staining was performed using rabbit anti-human cleaved caspase-3 (Asp175, 1:50, Cell Signaling, Danvers, USA), rabbit anti-human Bax (1:20, clone P-19, Santa Cruz Biotechnology, Santa Cruz, USA), mouse anti-human Bcl2 (1:20, clone 124, Dako Denmark A/S; Glostrup, Denmark), and rat anti-human caspase-8 (55kD full length and cleaved, active 18kD forms of caspase-8; 1:10, clone 1H10E4H10, Zymed Laboratories, San Francisco, USA) antibodies. Secondary antibodies were FITC-conjugated goat anti-rabbit or

goat anti-mouse IgG (both 1:80, Jackson ImmunoResearch Europe Ltd., Suffolk, UK), or Alexa Fluor® 488-conjugated goat anti-rat $\lg$ (g (1:200, Invitrogen). Cells were washed with PBS for $5 \mathrm{~min}$ at RT, fixed in cold acetone/methanol at $4^{\circ} \mathrm{C}$ for $8 \mathrm{~min}$, and washed again in PBS. Cells were incubated with primary antibodies at $4^{\circ} \mathrm{C}$ over night, washed $2 x$ with PBS for $5 \mathrm{~min}$ and incubated with respective secondary antibodies at $37^{\circ} \mathrm{C}$ for $30 \mathrm{~min}$ (all antibodies diluted in PBS). Cells were washed $2 \mathrm{x}$ with PBS for $10 \mathrm{~min}$ and nuclei were counterstained with DAPI $(0.1 \mu \mathrm{g} / \mathrm{ml}$, Sigma-Aldrich) at RT for $5 \mathrm{~min}$. Samples were covered with glycerol and immediately photodocumented using an IX81 fluorescence microscope equipped with an OBS CCD FV2T camera driven by cell^R. Primary antibodies were omitted in controls. All experiments were performed at least six times.

\section{Western blot}

Cells were collected as above and lysed in $100 \mu \mathrm{l}$ ice-cold lysis buffer $(60 \mathrm{mM}$ TRIS-HCl pH6.8, 1\% SDS, $1 \mathrm{mM} \mathrm{NaVO}_{4}$ [Merck KG, Darmstadt, Germany]). Samples were incubated at $99^{\circ} \mathrm{C}$ for $5 \mathrm{~min}$, homogenised by sonication for $30 \mathrm{~s}$, and centrifuged at $14,000 \mathrm{rpm}$ for $3 \mathrm{~min}$. Protein concentration was determined using the BCA protein assay (Perbio Science, Bonn, Germany). 5x loading buffer (10\% SDS, 15\% glycerol, $0.01 \%$ bromophenol blue, $20 \% 2$ mercaptoethanol, 0.3125M TRIS-HCl pH6.8 [Merck]) was added and equal amounts of protein $(40 \mu \mathrm{g} / \mathrm{lane})$ were loaded on $10 \%$ PAA gels and electrophoresed (running buffer 
$0.025 \mathrm{~mol} / /$ Tris, $0.2 \mathrm{~mol} / /$ glycine, $0.1 \%$ SDS pH8.8 [Merck]). Protein bands were blotted onto PVDF membranes (Roth) at $4^{\circ} \mathrm{C}$ over night by wet western blotting (transfer buffer $0.025 \mathrm{~mol} / \mathrm{I}$ Tris, $0.2 \mathrm{~mol} / \mathrm{l}$ glycine, $20 \%$ methanol). Blots were blocked in $5 \%$ non-fat dry milk in PBS/0.1\% tween-20 at RT for $1 \mathrm{~h}$. Membranes were then incubated with rabbit anti-human cleaved caspase-3 (1:200) or rabbit anti-human PARP p85 (caspase-cleaved 85kD fragment; 1:200, Promega Co., Madison, USA) at $4^{\circ} \mathrm{C}$ over night, or were incubated with mouse anti-human gamma-tubulin (1:7500, clone GTU-88, Sigma-Aldrich) at RT for 1h (all antibodies diluted in blocking solution). Detection was performed using HRP-conjugated goat anti-rabbit IgG (1:1000 for cleaved caspase-3, 1:5000 for cleaved PARP, Cell Signaling) or HRP-conjugated horse anti-mouse IgG (1:75000, Cell Signaling) diluted in blocking solution at RT for $1 \mathrm{~h}$ and subsequent chemiluminescence using the Amersham ECL western blotting detection system (GE Healthcare, Munich, Germany) on Hyperfilm ECL (GE Healthcare).

\section{RESULTS}

\section{Morphology and mitochondrial membrane potential}

Morphology of untreated and staurosporine-treated cells was analysed by DIC microscopy after 5days cultivation in the test media (fig 1A). Untreated cells showed polygonal morphology with few vacuoles and formed regular monolayers in SFM and F99 $9_{\text {HCEC }}$, while cells in MEM were enlarged and had increased numbers and sizes of vacuoles. Furthermore, a markedly lesser cell density was observed in MEM cultures. Proliferation seemed also slightly reduced in SFM with antibiotics and cells contained more vacuoles than in SFM without antibiotics. Staurosporine induced cell shrinkage and loss of intercellular contacts in all cultures, and in MEM also caused fragmentation of the cells. Intravital staining (fig 1B) 
revealed numerous mitochondria with depolarised membranes (green JC-1 fluorescence) in MEM-cultured cells irrespective of staurosporine treatment. In the other media, mitochondria of untreated cells had predominantly polarised membranes (red JC-1 fluorescence), and became depolarised only after staurosporine treatment.

\section{Flow cytometric analysis of apoptosis, necrosis and oxidative stress}

FACS analysis revealed that HCEC could be divided into four subpopulations after staurosporine treatment, namely healthy cells ( $\mathrm{PI}$ and YO-PRO-1 negative), YO-PRO-1 positive (apoptotic) cells, highly PI-positive (necrotic) and PI low-positive (apoptotic, see Zamai et al. 1996 and 2001) cells.[18,19] The number of healthy cells in untreated cultures was significantly higher in both SFM media $(95.6 \pm 1.6 \%, 95.6 \pm 1.9 \%)$ than in F99 $_{\text {HCEC }}$ $(87.5 \pm 2.0 \%)$ and MEM media $(79.1 \pm 2.8 \%$ and $81.9 \pm 4.4 \%)$, and was also significantly higher in $\mathrm{F} 9_{\mathrm{HCEC}}$ than in MEM+2\% FCS. Adding staurosporine significantly reduced the number of healthy cells in $\mathrm{F} 99_{\mathrm{HCEC}}(66.2 \pm 3.5 \%)$ and MEM media $(28.6 \pm 2.4 \%$ and $22.4 \pm 0.8 \%)$, but not in SFM media $(93.0 \pm 3.3 \%$ and $94.4 \pm 2.3 \%$ ) (fig $2 \mathrm{~A})$. The number of necrotic cells in untreated controls was significantly lower in both SFM media $(2.1 \pm 1.3 \%$ and $1.7 \pm 1.1 \%)$ than in the other media (F99 $9_{\text {HCEC }} 7.2 \pm 1.2 \%$; MEM $13.0 \pm 2.5 \%$ and $10.8 \pm 3.6 \%$ ). After staurosporine treatment, the number of highly PI-positive cells increased significantly in F99 ${ }_{\text {HCEC }}$ $(14.3 \pm 2.3 \%)$ and in MEM $(33.2 \pm 3.6 \%$ and $33.9 \pm 3.1 \%)$ compared to their untreated counterparts (SFM $2.7 \pm 2.5 \%$ and $1.8 \pm 1.0 \%$, not significant), (fig $2 \mathrm{~B}$ ). The number of YOPRO-1 positive cells increased significantly after staurosporine treatment in $\mathrm{F} 9_{\text {HCEC }}$ from $1.8 \pm 0.5 \%$ to $11.7 \pm 3.2 \%$ and in both MEM media from $1.0 \pm 0.2 \%$ to $21.1 \pm 6.4 \%$ and from $1.3 \pm 0.3 \%$ to $31.8 \pm 4.3 \%$, but not in SFM media (from $0.8 \pm 0.2 \%$ to $2.1 \pm 1.1 \%$ and from $0.9 \pm 0.5 \%$ to $1.9 \pm 1.0 \%$ ) compared to untreated controls (fig $2 \mathrm{C}$ ). The number of PI low positive cells in untreated controls was significantly fewer in SFM media $(1.5 \pm 0.4 \%$ and $1.8 \pm 0.9 \%)$ than in the other media ( $\mathrm{F} 99_{\mathrm{HCEC}} 3.5 \pm 0.8 \%$; MEM $6.8 \pm 0.3 \%$ and $\left.6.0 \pm 0.7 \%\right)$ and was also significantly lower in $\mathrm{F} 99_{\mathrm{HCEC}}$ compared to $\mathrm{MEM}+2 \% \mathrm{FCS}$. Staurosporine-induced 
cell stress was significantly higher in both MEM media $(17.1 \pm 4.1 \%$ and $11.9 \pm 0.8 \%)$ and in F99 ${ }_{\text {HCEC }}(7.8 \pm 1.8 \%)$, but not in SFM media $(2.2 \pm 0.6 \%$ and $1.9 \pm 0.5 \%)$ (fig $\left.2 \mathrm{D}\right)$. The number of cells with fragmented chromatin (subG1-DNA-content) was significantly lower in untreated SFM cultures $(4.2 \pm 1.0 \%$ and $4.4 \pm 1.8 \%)$ than in untreated MEM media cultures $(14.2 \pm 3.7 \%$ and $8.6 \pm 1.8 \%$ ). Staurosporine-induced DNA fragmentation was significantly higher in MEM media $(41.9 \pm 2.2 \%$ and $48.0 \pm 2.9 \%)$ and in $\mathrm{F} 99_{\mathrm{HCEC}}(18.2 \pm 4.5 \%)$ compared to their untreated counterparts, but not in SFM media $(8.7 \pm 3.5 \%$ and $7.7 \pm 3.1 \%)$ (fig $2 \mathrm{E})$. ROS production in untreated control cultures was significantly lower in MEM+5\% FCS (32.1 \pm 2.7$)$ than in the other media (F99 HCEC $_{9} 98.2 \pm 45.7$; MEM+2\% FCS 44.0 \pm 5.4 ; SFM 86.2 \pm 19.7 and $55.9 \pm 20.2$ ) and was also significantly lower in MEM+2\% FCS than in SFM. Cells cultured in MEM or F99 $9_{\text {HCEC }}$ showed a significantly higher ROS production after treatment with $\mathrm{H}_{2} \mathrm{O}_{2}$ (MEM 192.1 \pm 51.3 and $\left.97.4 \pm 7.3, \mathrm{~F} 9_{\mathrm{HCEC}} 238.2 \pm 50.6\right)$ compared to their untreated counterparts, but not in SFM media (116.7 \pm 14.8 and $96.9 \pm 9.7)$ (fig $2 F)$.

\section{Immunocytochemical analysis of apoptotic parameters}

Upon staurosporine treatment, cells in MEM and F99 ${ }_{\mathrm{HCEC}}$ cultures showed stronger staining for cleaved caspase-3 (fig 3A), cleaved caspase-8 (fig 3B), Bax (fig 4A), and Bcl-2 (fig 4B), and to some extent stronger staining for cleaved caspase-8 in cells cultured in SFM with antibiotics. The staining pattern for caspase-8 and Bax changed from a single perinuclear, punctate localisation in untreated controls to a diffuse cytoplasmic appearance. Especially cells cultured in MEM media were highly susceptible to apoptosis, indicated by pronounced Bcl-2 and Bax positivity already in untreated cultures. Interestingly, cells cultured in SFM seemed less affected by staurosporine, since staurosporine failed to induce up-regulation of $\mathrm{Bcl}-2$ and the other tested apoptosis markers. Omission of the primary antibodies in negative control stainings confirmed specificity of the staining (fig 5). Western blotting (fig 3C) revealed more cleaved PARP and cleaved caspase-3 after staurosporine treatment in all cultures, with cells cultured in MEM media and F99 $9_{\text {HCEC }}$ producing markedly higher amounts 
of cleaved PARP and cleaved caspase-3 compared to cells cultured in SFM media. Besides, cleaved caspase- 3 could also be detected in untreated cells cultured in medium F99 ${ }_{\text {HCEC }}$, and cleaved PARP could also be detected in untreated cells cultured in MEM+5\% FCS.

\section{DISCUSSION}

Endothelial cell density and morphology are the two main criteria for evaluating the quality of corneal grafts before keratoplasty, both being influenced by storage conditions. European eye banks favour long-term storage at $30-37^{\circ} \mathrm{C}$, and most commonly a MEM-based medium is used. MEM has a reduced nutrient content and needs to be supplemented with fetal calf serum to maintain cell survival. Improvements in cell and organ culture techniques and updated legal guidelines for handling tissues for transplantation require serum replacement by defined, ideally humanised, factors. Previous investigations showed that metabolic requirements of corneal endothelial cells are quite particular and are only inadequately met by MEM in corneal endothelial cell and corneal organ culture.[10-13,20]

The results obtained here support these former reports and clearly show that nutrient deficiency in MEM does not only lead to a reduced metabolic and proliferative activity, but results in an elevated susceptibility to apoptotic cell death in HCEC. Dramatic morphological changes of HCEC cultured in MEM, like pronounced vacuolisation, are key features of a reduced viability and are already visible in untreated control cultures. Signs of cell death, such as chromatin fragmentation, mitochondrial membrane depolarisation, and labelling with

$\mathrm{PI}$ and YO-PRO-1, can be detected in MEM-cultured HCEC even without exogenously inducing apoptosis. Adding the apoptosis-inducer staurosporine to MEM-cultured cells 
resulted in a marked increase of these indicators and also in an up-regulation of the apoptotic markers caspase-3 and PARP and hence also their cleaved forms, as detected by western blotting. Furthermore, a higher staining intensity for Bax and cleaved caspase- 8 was noted irrespective of the amount of serum added. This increase in staining intensity was accompanied by cytoplasmic spreading of the formerly single punctate pattern in untreated and healthy cells, which strongly resembled the staining pattern of p53, a transcription factor that regulates transcription of molecules associated to the apoptotic pathways and localises in close proximity with caspase- 8 and Bax, amongst others, in healthy cells. Upon induction of apoptosis caspase-8 is up-regulated, cleaved and distributed into the cytoplasm. Likewise, Bax is up-regulated, oligomerised and also distributed to the cytoplasm.[21-23] Up-regulation of $\mathrm{Bcl}-2$, an anti-apoptotic protein which is expressed in organ-cultured human cornea $[24,25]$, may be regarded as a protective mechanism sustained by the cells. For example, the higher amount of $\mathrm{Bcl}-2$ in untreated cultures kept in MEM+2\% FCS compared to the other untreated cultures may indicate that nutrient supply in this medium is insufficient and the cells up-regulate Bcl-2 to counteract death by starvation. Contrasting, HCEC in SFM appeared to be protected from cell death despite the lack of serum, as the examined apoptotic factors were significantly lower under control conditions and did not increase significantly after staurosporine administration. It also appeared that addition of antibiotics, which can be noxious under serum-free conditions, was well tolerated in SFM.

ROS are formed as a physiological product of respiration, hence higher ROS production in cells in SFM and F99 ${ }_{\text {HCEC }}$ under control conditions reflects a higher metabolic activity. ROS production does not increase significantly under administration of $\mathrm{H}_{2} \mathrm{O}_{2}$ in SFM, indicating that HCEC in SFM are protected against oxidative stress by utilising anti-oxidative or compensatory mechanisms. Contrasting, HCEC in MEM form only little ROS under control conditions, but increase ROS production more than double under $\mathrm{H}_{2} \mathrm{O}_{2}$, pointing to a reduced respiratory and metabolic activity and insufficient anti-oxidative capacity of the cells. This is 
further substantiated by the observed depolarised mitochondrial membranes in MEM-fed control cultures.

In summary, the results show that cells cultured in MEM media seem susceptible to cell death already in the absence of exogenous noxious stimuli, while HCEC cultured in SFM seem to be protected from cell death even when the apoptosis-inducer staurosporine is added. The nutritive conditions in MEM therefore seem to be insufficient to sustain adequate compensatory mechanisms against oxidative cell stress. Thus Human Endothelial-SFM is superior to conventionally used MEM in promoting HCEC survival in vitro cell cultures. It is known that cultured cells react more sensitive to stimuli than cells in situ, and it can be assumed that the microenvironment of corneal endothelial cells in situ may contain protective factors that prevent endothelial cell death in MEM-based organ cultured donor corneas in such an extensive way as was observed in our experiments. However, based on our results and with respect to european laws and guidelines on tissue handling we suggest that the methods of organ cultivation of donor corneas should be improved. A multi-centric clinical trial to transplant SFM-stored corneas vs. MEM-stored corneas was initiated in Germany (registered at clinicaltrials.gov, identifier NCT00623584). 


\section{REFERENCES AND ACKNOWLEDGEMENTS}

1 Armitage WJ, Easty DL. Factors Influencing the Suitability of Organ-Cultured Corneas for Transplantation. Invest Ophthalmol Vis Sci. 1997;38:16-24.

2 Abott RL. Long-term changes in corneal endothelium following penetrating keratoplasty. Ophthalmology. 1983;90:676-685.

3 Lee HS, Kim MS. Influential factors on the survival of endothelial cells after penetrating keratoplasty. Eur J Ophthalmol. 2009;19:930-935.

4 Borderie VM, Boëlle PY, Touzeau O, et al. Predicted long-term outcome of corneal transplantation. Ophthalmology. 2009;116(12):2354-2360.

5 Bertelmann E, Pleyer U, Rieck P. Risk factors for endothelial cell loss post-keratoplasty. Acta Ophthalmol Scand. 2006;84:766-770.

6 Schneider EL, Braunschweiger K, Mitsui Y. The effect of serum batch on the in vitro lifespans of cell cultures derived from old and young human donors. Exp Cell Res. 1978;115:47-52.

7 Engelmann K, Winter R. [Quality control in the corneal bank-a necessary measure?] Klin Monatsbl Augenheilkd. 1993;203:262-268.

8 Directive 2004/23/EC of the European Parliament and of the Council of 31 March 2004 on setting standards of quality and safety for the donation, procurement, testing, processing, preservation, storage and distribution of human tissues and cells. The European Parliament and the Council of the European Union. Off. J. Eur. Comm. L102, 48-58 (2004).

http://eur-lex.europa.eu/LexUriServ/site/en/oj/2004/I_136/I_13620040430en00010033.pdf

9 Commission Directive 2006/17/EC of 8 February 2006 implementing Directive 2004/23/EC of the European Parliament and of the Council as regards certain technical requirements for the donation, procurement and testing of human tissues and cells. The European Parliament and the Council of the European Union. Off. J. Eur. Comm. L38, 40-52 (2006). 
http://eur-lex.europa.eu/LexUriServ/site/en/oj/2006/I_038/I_03820060209en00400052.pdf

10 Møller-Pedersen T, Hartmann U, Møller HJ, et al. Evaluation of potential organ culture media for eye banking using human donor corneas. Br J Ophthalmol. 2001;85:10751079.

11 Møller-Pedersen T, Hartmann U, Ehlers N, et al. Evaluation of potential organ culture media for eye banking using a human corneal endothelial cell growth assay. Graefe`s Arch Clin Exp Ophthalmol. 2001;239:778-782.

12 Hempel B, Bednarz J, Engelmann K. Use of a serum-free medium for long- term storage of human corneas. Influence on endothelial cell density and corneal metabolism. Graefe`s Arch Clin Exp Ophthalmol. 2001;239:801-805.

13 Bednarz J, Doubilei V, Wollnik PCM, et al. Effect of three different media on serum free culture of donor corneas and isolated human corneal endothelial cells. $\mathrm{Br} \mathrm{J}$ Ophthalmol. $2001 ; 85: 1416-1420$.

14 Bednarz J, Teifel M, Friedl P, et al. Immortalization of human corneal endothelial cells using electroporation protocol optimized for human corneal endothelial and human retinal pigment epithelial cells. Acta Ophthalmol Scand. 2000;78:130-136.

15 Valtink M, Gruschwitz R, Funk RH, et al. Two Clonal Cell Lines of Immortalized Human Corneal Endothelial Cells Show either Differentiated or Precursor Cell Characteristics. Cells Tissues Organs. 2008;187:268-294.

16 Thuret G, Chiquet C, Herrag S, et al. Mechanisms of staurosporine induced apoptosis in a human corneal endothelial cell line. Br J Ophthalmol. 2003;87:346-352.

17 Waibel M, Kramer S, Lauber K, et al. Mitochondria are not required for death receptormediated cytosolic acidification during apoptosis. Apoptosis. 2007;12:623-630.

18 Zamai L, Falcieri E, Marhefka G, et al. Supravital exposure to propidium iodide identifies apoptotic cells in the absence of nucleosomal DNA fragmentation. Cytometry. 1996;23:303-311.

19 Zamai L, Canonico B, Luchetti F, et al. Supravital exposure to propidium iodide identifies apoptosis on adherent cells. Cytometry. 2001;44:57-64. 
20 Rieck PW, Gigon M, Jaroszewski J, et al. Increased endothelial survival of organ-cultured corneas stored in FGF-2-supplemented serum-free medium. Invest Ophthalmol Vis Sci. 2003;44:3826-3832.

21 Han J, Goldstein LA, Hou W, et al. Regulation of mitochondrial apoptotic events by p53mediated disruption of complexes between anti-apoptotic Bcl-2 members and Bim. J Biol Chem. Published Online First: 19 April 2010. doi:10.1074/jbc.M109.081042.

22 Yao Z, Duan S, Hou D, et al. Death effector domain DEDa, a self-cleaved product of caspase-8/Mch5, translocates to the nucleus by binding to ERK1/2 and upregulates procaspase-8 expression via a p53-dependent mechanism. Embo J. 2007;26:1068-1080.

23 Haluska P Jr, Saleem A, Rasheed Z, et al. Interaction between human topoisomerase I and a novel RING finger/arginine-serine protein. Nucleic Acids Res. 1999;27:2538-2544.

24 Gain P, Thuret G, Chiquet C, et al. In situ immunohistochemical study of Bcl-2 and heat shock proteins in human corneal endothelial cells during corneal storage. $\mathrm{Br} \mathrm{J}$ Ophthalmol. 2001;85:996-1000.

25 Yamamoto K, Ladage PM, Ren DH, et al. Bcl-2 expression in the human cornea. Exp Eye Res. 2001;73:247-255.

\section{Acknowledgements}

We wish to thank Ms B. Rost, Ms S. Bramke and Ms A. Neisser for technical assistance. 


\section{LEGENDS}

Figure 1 HCEC morphology and polarization state of mitochondrial membranes. Cells were cultured in the respective test media for $5 \mathrm{~d}$, and then part of each culture was treated with $0.5 \mu \mathrm{mol} / \mathrm{l}$ staurosporine for $4 \mathrm{~h}$ at $37^{\circ} \mathrm{C}$ to induce apoptosis. (A) Morphology of the cells viewed by DIC microscopy. (B) Intravital staining with JC-1 indicates mitochondria with predominantly polarised (red) membranes in untreated controls in SFM and F99 HCEC $_{\text {, and }}$ depolarised (green) mitochondrial membranes in untreeated MEM controls and in all media after addition of staurosporine. Scale bar $100 \mu \mathrm{m}$.

Figure 2 Flow cytometric analysis of HCEC. Cells were cultured in the respective test media for $5 \mathrm{~d}$, then part of each culture was treated with $0.5 \mu \mathrm{mol} / \mathrm{l}$ staurosporine for $4 \mathrm{~h}$ at $37^{\circ} \mathrm{C}$ to induce apoptosis (A-E) or was treated with $200 \mu \mathrm{mol} / \mathrm{l} \mathrm{H}_{2} \mathrm{O}_{2}$ for $2.5 \mathrm{~h}$ at $37^{\circ} \mathrm{C}$ to induce oxidative stress (F). (A) Number of healthy (PI-/YO-PRO-1 negative) cells, (B) number of necrotic (PI-positive) cells, (C) number of apoptotic (YO-PRO-1 positive) cells, (D) number of apoptotic (low PI-positive) cells, (E) number of cells with fragmented nuclei (sub G1 DNAcontent), (F) ROS production was visualised by means of $\mathrm{CM}-\mathrm{H}_{2} \mathrm{DCFDA}$ staining, fluorescence intensity is given in arbitrary units. Data are given as mean $\pm S D\left({ }^{*} p<0.05\right)$. White bars: untreated control cultures, grey bars: treated with staurosporine, black bars: treated with $\mathrm{H}_{2} \mathrm{O}_{2}$.

Figure 3 Determination of cleaved caspase-3, full length and cleaved caspase-8 and cleaved PARP. Cells were cultured in 5 test media for $5 d$ and part of each culture was treated with $0.5 \mu \mathrm{mol} / / \mathrm{l}$ staurosporine for $4 \mathrm{~h}$ at $37^{\circ} \mathrm{C}$ to induce apoptosis. Cells were then fixed and stained with antibodies against cleaved caspase-3 (A) and full length and cleaved caspase-8 (B). Scale bar $100 \mu \mathrm{m}$. (C) Western blot analysis of cleaved caspase-3 and cleaved PARP (loading control: $\gamma$-tubulin).

Figure 4 Determination of Bax and Bcl-2. Cells were cultured in 5 test media for $5 \mathrm{~d}$ and part of each culture was treated with $0.5 \mu \mathrm{mol} / / \mathrm{l}$ staurosporine for $4 \mathrm{~h}$ at $37^{\circ} \mathrm{C}$ to induce apoptosis. Cells were then fixed and stained with antibodies against Bax (A) and Bcl-2 (B). Scale bar $100 \mu \mathrm{m}$. 
Figure 5 Negative control stainings of HCEC cultured in MEM+2\% FCS and treated with staurosporine for $4 \mathrm{~h}$ at $37^{\circ} \mathrm{C}$ to induce apoptosis. The primary antibodies were omitted. (A) cleaved caspase-3, (B) full length and cleaved caspase-8, (C) Bax, (D) Bcl-2; scale bar $100 \mu \mathrm{m}$. 


\section{COPYRIGHT LICENCE STATEMENT}

"The Corresponding Author has the right to grant on behalf of all authors and does grant on behalf of all authors, an exclusive licence (or non exclusive for government employees) on a worldwide basis to the BMJ Publishing Group Ltd to permit this article (if accepted) to be published in BJO and any other BMJPGL products and sublicences such use and exploit all subsidiary rights, as set out in our licence

(http://bjo.bmijournals.com/misc/ifora/licenceform.shtml)."

\section{COMPETING INTERESTS}

Competing Interest: None declared.

\section{FUNDING}

no funding

\section{COLOUR FIGURES AND COSTS}

This manuscript contains 3 colour figures. The costs for printing the 3 colour figures will be taken over by

Institute of Anatomy

Medical Faculty at the TU Dresden

Fetscherstr. 74

01307 Dresden

Germany

The bill may as well be sent to the Corresponding Author. 


\section{- staurosporine + staurosporine}

SFM

+ antibiotics

SFM

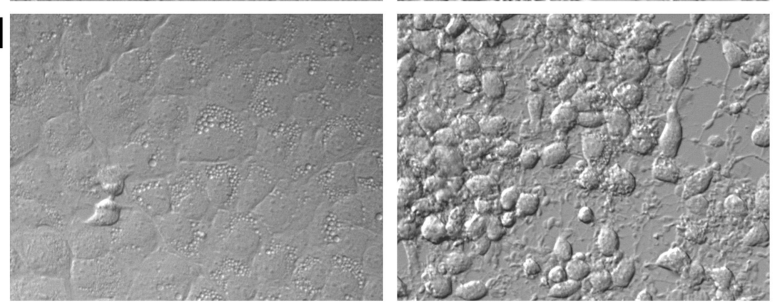

F99HCEC
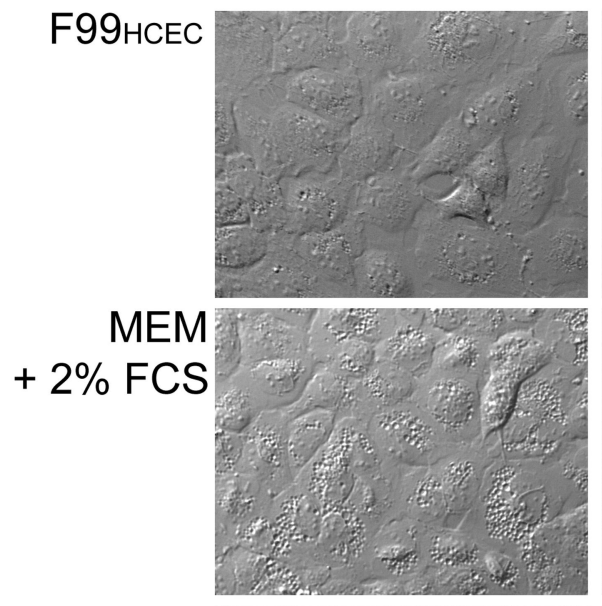

MEM
$+5 \%$ FCS

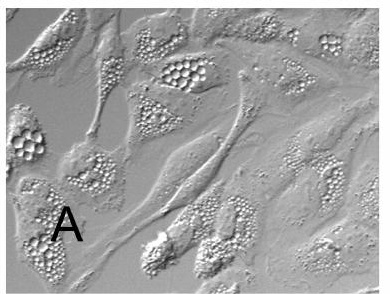

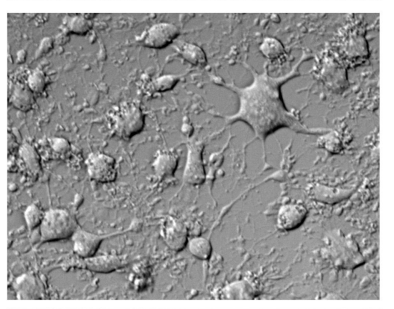
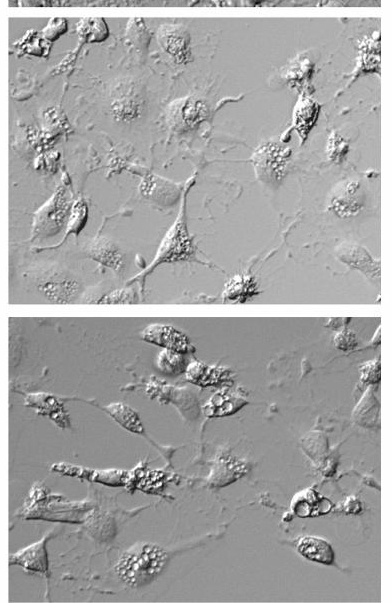

\section{- staurosporine}
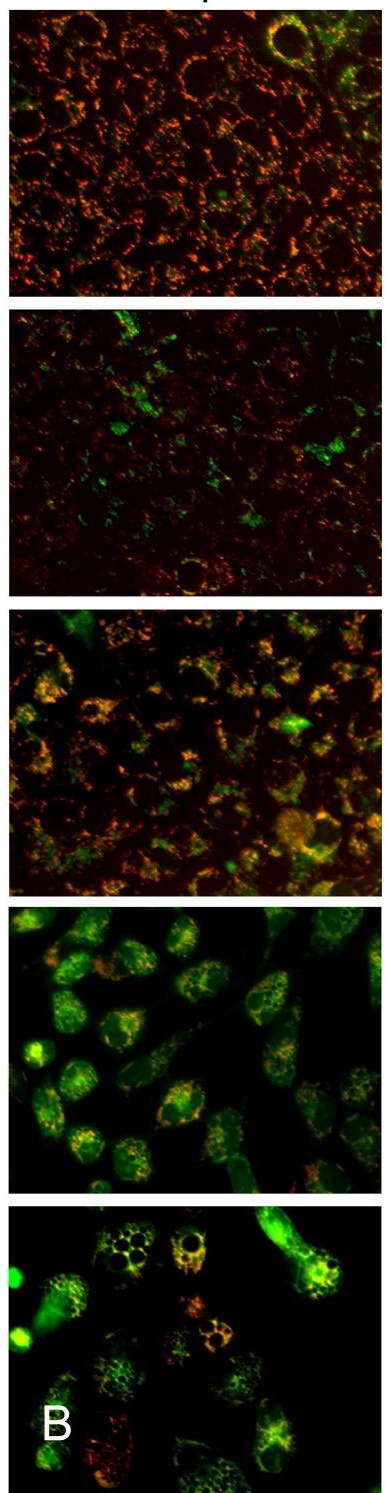

+ staurosporine
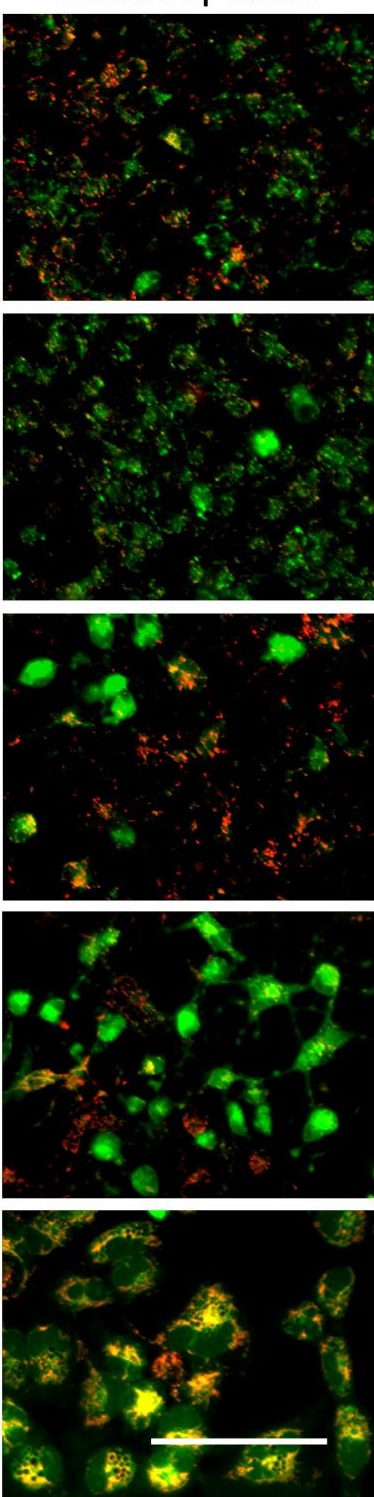
- staurosporine

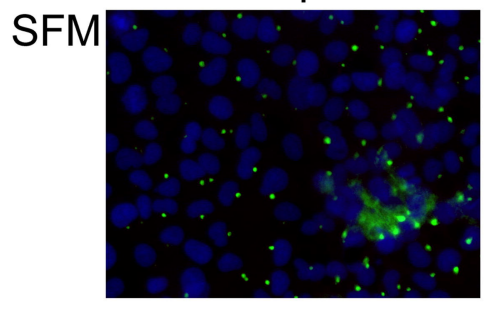

SFM
+ antibiotics

SFM
+ antibiotics

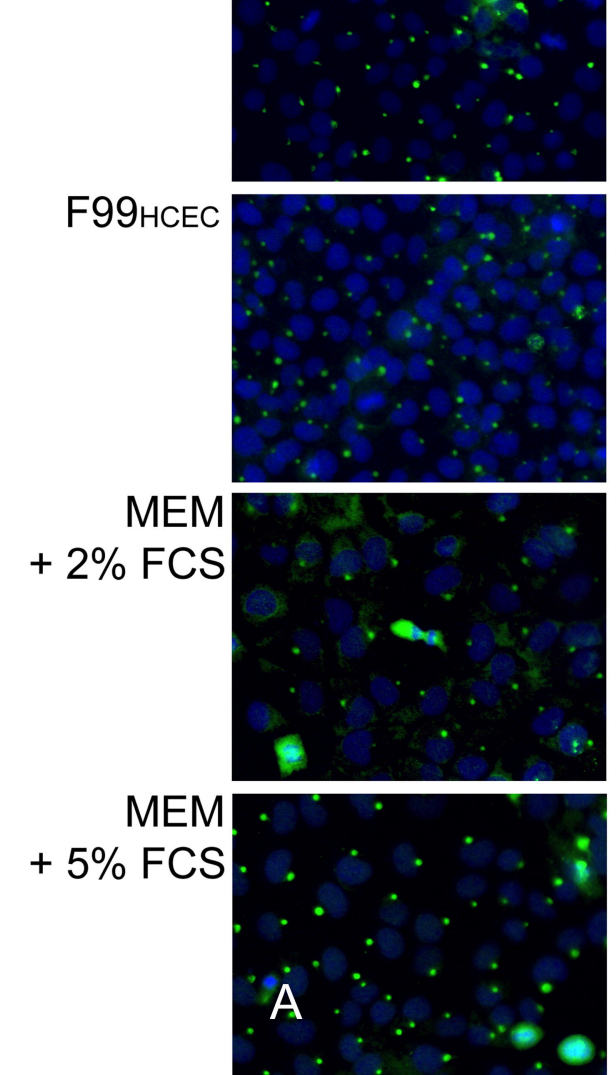

+ staurosporine

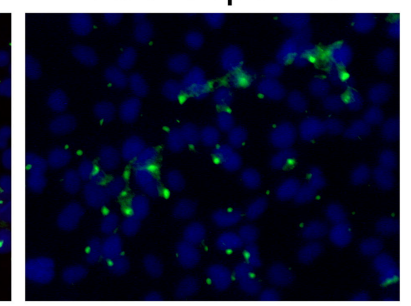

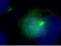
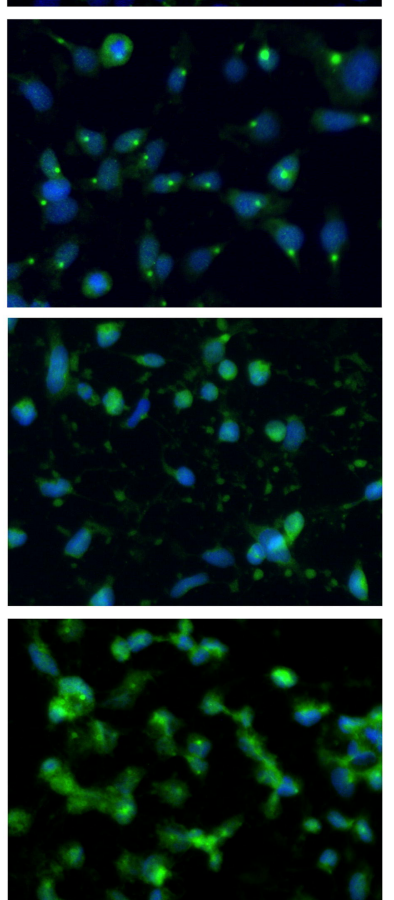

- staurosporine

+ staurosporine
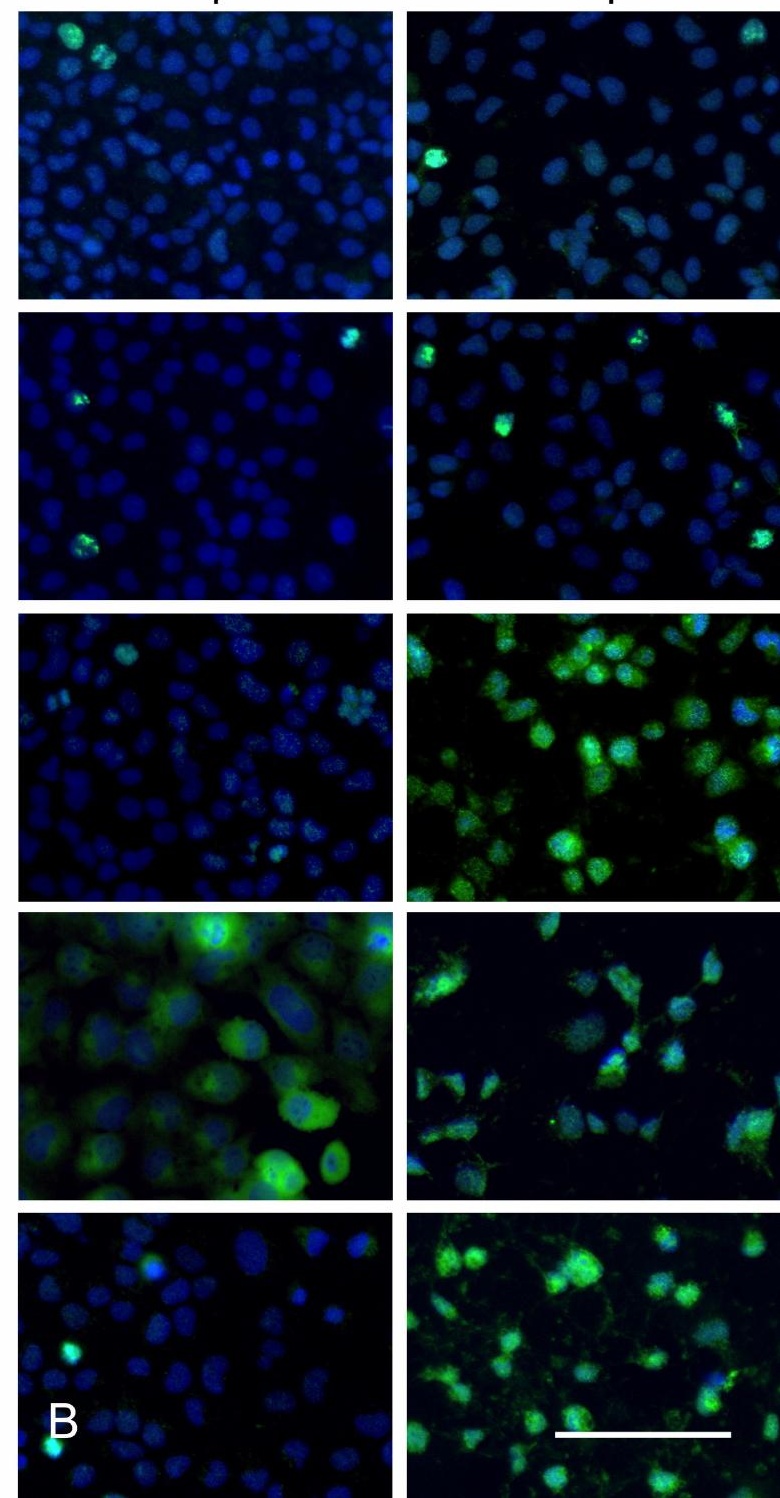
A

B

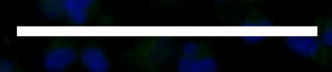

